УДК 342.565 .2

DOI https://doi.org/10.51989/NUL.2021.5.10

\title{
НОРМИ МИТНОГО КОДЕКСУ УКРАЇНИ ЯК ПРЕДМЕТ КОНСТИТУЦІЙНОГО КОНТРОЛЮ
}

\section{Томкіна Олена Олексіївна,}

кандидат юридичних наук, провідний науковий співробітник відділу дослідження проблем взаємодії держави та громадянського суспільства Київського регіонального центру Національної академії правових наук України

Стаття присвячена проблемі законодавчого визначення адміністративної відповідальності за порушення митних правил, зокрема за дії, спрямовані на неправомірне звільнення від сплати митних платежів чи зменшення їхнього розміру, а також інші протиправні дії, спрямовані на ухилення від сплати митних платежів (стаття 485 Митного кодексу України).

Положення статті 485 Митного кодексу України оскарженні до Конституційного Суду України з мотивів їхньої невідповідності Конституції України. Автори конституційних скарг обґрунтовують неконституційність положень цієї статті тим, що абсолютно визначена санкція, неможливість ії зменшення і відсутність альтернативних видів санкцій за вчинення відповідного правопорушення не дають змоги застосовувати цю норму з урахуванням принципу індивідуалізації юридичної відповідальності правопорушника, що суперечить частині 2 статті 62 Конституції України.

Автори клопотань також указують на те, що невідповідність санкції статті 485 Митного кодексу України засадам індивідуалізації юридичної відповідальності порушує встановлені Конституцією України право особи володіти, користуватися і розпоряджатися власністю (стаття 41), право особи на достатній життєвий рівень для себе і своєї сім'ї, що включає достатне харчування, одяг, житло (стаття 48).

Оскарження положень статті 485 Митного кодексу України актуалізує проблему забезпечення конституційності митного законодавства України загалом, оскільки, окрім оспорюваних положень зазначених статей цього Кодексу, є й інші формальні склади митних правопорушень, що містять абсолютно визначені санкції та/або є юридично невизначеними.

Диспозиція норми права, що викладена у статті 485 Митного кодексу України, сконструйована законодавцем у вигляді «відкритого» (незавершеного) переліку протиправних дій, що спрямовані на ухилення від сплати митних платежів. Вказівка на ознаку протиправності «інших» дій та їхню мету не забезпечує чіткості, однозначності, зрозумілості сформульованого законодавчого припису, отже, його передбачуваності для суб'єктів права. Таке використання засобів законодавчої техніки під час визначення адміністративного правопорушення перетворює диспозицію норми права на «гумову» і загрожує законності правозастосування. Окрім цього, такий законодавчий припис $\epsilon$ корупціогенним чинником, адже відкриває шлях до службових зловживань, довільного, на основі суб'єктивних оцінок, а не формально визначених ознак, тлумачення норми права.

Отже, є підстави для висновку, що оскільки диспозиція норми права, шо викладена у статті 485 Митного кодексу України, сформульована нечітко та неоднозначно, приписи цієї статті не можна вважати юридично визначеними в аспекті їхньої передбачуваності для суб'єктів правозастосування.

Санкція статті 485 Митного кодексу України $\epsilon$ абсолютно визначеною, оскільки безальтернативно передбачає тільки один вид адміністративного стягнення за визначене в цій статті митне правопорушення - штраф, не встановлює водночас допустимі для відповідного правопорушення межі його застосування, отже, не забезпечує індивідуальний характер юридичної відповідальності осіб, визнаних винними у правопорушенні.

Зважаючи на викладене, митне законодавство України має розвиватися шляхом установлення відносно визначених і альтернативних санкцій, що дозволяє індивідуалізувати адміністративну відповідальність за порушення митних правил.

Ключові слова: Митний кодекс України, конституційний контроль, верховенство права, юридична визначеність, принцип індивідуалізації юридичної відповідальності. 


\section{Tomkina Olena. Norms of the Customs Code of Ukraine as a subject of constitutional control}

The article is devoted to the problem of legislative definition of administrative responsibility for customs offence, in particular for actions aimed at illegal exemption from payment of customs duties or reduction of their amount, as well as other illegal actions aimed at evasion of customs duties (Article 485 of the Customs Code).

Provisions of Article 485 of the Customs Code of Ukraine are appealed to the Constitutional Court of Ukraine on the grounds of their inconsistency with the Constitution of Ukraine. The authors of the appropriate constitutional complaints substantiate the unconstitutionality of this Article by the fact that its absolutely defined sanction, impossibility of its reduction and absence of alternative types of sanctions for committing the relevant offense do not allow to apply this norm taking into account the principle of individualization of legal responsibility of the offender, what contradicts the second part of the Article 62 of the Constitution of Ukraine.

The petitioners also point out that the inconsistency of the sanction of Article 485 of the Customs Code of Ukraine with the principles of individualization of legal responsibility violates the right of a person to own, use and dispose of property (Article 41), the right to a sufficient standard of living for himself and his family, which includes adequate food, clothing, housing (Article 48).

The appeal against the provisions of Article 485 of the Customs Code of Ukraine highlights the problem of ensuring the constitutionality of customs legislation of Ukraine in general, because in addition to the disputed provisions of specified articles of this Code, other formal customs offenses provided for in the Customs Code of Ukraine, and contain absolutely certain sanctions and / or are legally indefinite.

The disposition of the rule of law set shown in Article 485 of the Customs Code of Ukraine is constructed by the legislator in the form of an "open" (i.e. incomplete) list of illegal actions. In this case, the indication of the illegality of these "other" actions and their purpose does not provide clarity, unambiguity, clarity of the formulated legislative provision, and hence its predictability for the subjects of law. Such use of legislative techniques in determining an administrative offense turns the disposition of the rule of law into a "rubber" and threatens the legality of law enforcement. In addition, such legislative provision is a corruptogenic factor, because it opens the way to mismanagement, arbitrary, i.e. on the basis of subjective assessments, rather than formally defined features, the interpretation of the rule of law.

Thus, there are reasons to conclude that since the disposition of the rule of law set forth in Article 485 of the Customs Code of Ukraine is vague and ambiguous, the provisions of this article cannot be considered legally defined in terms of their predictability for law enforcement entities.

The sanction of Article 485 of the Customs Code of Ukraine is absolutely defined, as it provides for only one type of administrative penalty for the customs violation, which is defined in this article as a fine, without establishing acceptable limits for its application, and thus does not provide individual legal liability found guilty of an offense under this article.

Considering the above, the customs legislation of Ukraine should be developed by establishing relatively specific and alternative sanctions that allows to individualize the administrative responsibility for violating customs rules.

Key words: Customs Code of Ukraine, constitutional control, legal certainty, principle of individualization of legal responsibility.

Постановка проблеми. Із запровадженням в Україні інституту конституційної скарги предметом конституційного контролю постали окремі положення Митного кодексу України (далі - МК України) щодо адміністративної відповідальності за порушення митних правил, а саме положення ст. ст. 471 і 485 МК України.

Вирішення питання про відповідність Конституції України (конституційність) окремих положень абз. 2 ст. 471 МК України відбулося в рішенні Конституційного Суду України (далі - КСУ, Суд) від
21 липня 2021 р. № 3-p(II) / 2021 [1]. Цим рішенням оспорювані положення визнані такими, що не відповідають Конституції України ( $\epsilon$ неконституційними), оскільки суперечать приписам ч. 1 ст. 8, ч. ч. 1, 4, 6 ст. 41, ч. 1 ст. 64 Конституції України.

Нині на розгляді КСУ перебувають справи за конституційними скаргами Г.С. Барсегяна (2019 р.) та Н.М. Ліненко (2021р.) щодо відповідності Конституції України (конституційності) положень ст. 485 МК України (ухвалою Другого сенату КСУ від 16 червня 2021 р. № 4-уп(II)/2021 провадження 
у справах за цими скаргами об'єднані в одне конституційне провадження).

На думку суб'єктів права на конституційну скаргу, встановлення законодавцем у ч. 1 ст. 485 МК України абсолютно визначеної санкції, неможливість її зменшення і відсутність альтернативних видів санкцій за вчинення відповідного правопорушення не дають змоги застосовувати цю норму з урахуванням принципу індивідуалізації юридичної відповідальності правопорушника, що суперечить ч. 2 ст. 62 Конституції України.

Автори клопотань також указують на те, що невідповідність санкції ч. 1 ст. 485 МК України конституційним засадам індивідуалізації юридичної відповідальності порушує встановлені Конституцією України право особи володіти, користуватися і розпоряджатися власністю (ст. 41), право особи на достатній життєвий рівень для себе і своєї сім'ї, що включає достатнє харчування, одяг, житло (ст. 48) [2].

Конституційне оскарження положень ст. ст. 471 і 485 МК України актуалізує проблему забезпечення конституційності митного законодавства України загалом, оскільки, окрім оспорюваних положень зазначених статей МК України, $\epsilon$ й інші формальні склади митних правопорушень, що містять абсолютно визначені санкції та/або є юридично невизначеними.

Метою статті $\epsilon$ теоретико-правовий аналіз положень ст. 485 МК України в контексті принципів юридичної визначеності й індивідуалізації юридичної відповідальності. Стаття виконана в межах фундаментальної теми «Взаємодія правової держави, громадянського суспільства та особи: правові аспекти, практичні реалії, прогностичні зміни» (номер державної реєстрації 0121U100031), яка виконується Відділом дослідження проблем взаємодії держави та громадянського суспільства Київського регіонального центру Національної академії правових наук України.

\section{Виклад основного матеріалу.} В Україні на конституційному рівні (ст. 8 Конституції України) визнається і діє принцип верховенства права («правовладдя»), одним з основних елементів якого $€$ юридична визначеність. В аспекті останньої «ідея правовладдя передбачає систему чітких та передбачуваних при- писів права, відповідно до яких кожному належить право на ставлення до нього з боку всіх суб'єктів ухвалення рішень на основі гідності, рівності й розумності та відповідно до приписів права, а також право на можливість звернутися з оскарженням рішень до незалежних і безсторонніх судів у рамках справедливих судових процедур»; тобто «будь-який припис права має бути приступним і передбачуваним» $[3$, с. 9, 17].

Передбачуваність означає не лише те, що приписи акта права мають бути (де можливо) проголошеними ще до їхньої імплементації, а й що вони мають бути передбачуваними за своїми наслідками: їх має бути сформульовано з належною чіткістю та зрозумілістю, щоби суб'єкти права мали змогу впорядкувати свою поведінку згідно з ними [3, с. 22].

Стосовно принципу юридичної визначеності КСУ у своїх рішеннях послідовно наголошує, що цей принцип випливає з ідей рівності і справедливості, означає ясність, зрозумілість, недвозначність правової норми, ії̈ передбачуваність (прогнозованість) для забезпечення стабільного правового становища людини, уникнення необмеженого правозастосування і сваволі. За цим принципом особа має право у своїх діях розраховувати на розумну та передбачувану стабільність законодавства та можливість передбачати наслідки застосування норм права. Тож держава зобов'язана запроваджувати таке юридичне регулювання, яке відповідає конституційним нормам і принципам, необхідне для забезпечення реалізації прав і свобод кожної особи та їхнього ефективного поновлення [4].

Реалізація принципу юридичної визначеності набуває особливого значення під час визначення правопорушення та юридичної відповідальності за його вчинення, оскільки застосуванням до винної особи заходів державно-правового примусу істотно обмежуються їі права і свободи. Розпливчасті (нечітко визначені) формулювання приписів актів права, зокрема нормативної конструкції складу правопорушення, неминуче породжують розходження в юридичній інтерпретації, зумовлюють свавільне правозастосування, нівелюють, зрештою, законність правової 
кваліфікації та притягнення особи до юридичної відповідальності.

Аспект передбачуваності актів права має велике значення в контексті конвенційного принципу «ніякого покарання без закону», який закріплений у ст. 7 Конвенції про захист прав людини та основоположних свобод: «нікого не може бути визнано винним у вчиненні будь-якого кримінального правопорушення на підставі будь-якої дії чи бездіяльності, яка на час її вчинення не становила кримінального правопорушення згідно з національним законом або міжнародним правом» [5].

Термін «закон», як зазначив Європейський суд з прав людини (далі - ЄСПЛ), несе якісні вимоги, включно з тими, що стосуються доступності та передбачуваності. Ці якісні вимоги повинні бути дотримані як у розрізі визначення правопорушення, так і покарання, яке це правопорушення спричиняє. ЄСПЛ наголошує, що закон має бути доступним для зацікавлених осіб та сформульованим із належною точністю, щоб надати їм можливість регулювати свою поведінку, щоби бути здатними - за потреби, за відповідної консультації - передбачати тією мірою, що $є$ розумною за відповідних обставин, наслідки, які може спричинити його дія [6].

Вищенаведеним підтверджується аксіоматичне у праві положення, що протиправність діяння як формально юридична ознака правопорушення означає визначеність діяння в законі. Тобто діяння $\epsilon$ протиправним, якщо воно правом заборонено. У вітчизняному законодавстві це зафіксовано в п. 22 ч. 1 ст. 92 Конституції України.

Категорія форми для пізнання права, як підкреслюється в літературі, $\epsilon$ дуже важливою, тому що від неї залежить його юридична сила, місце у правовій системі, ефективність регулювання. Формально визначений характер норми права полягає в: однозначності сприйняття суб'єктами права її змісту, що досягається точністю і ясністю мовної форми; у текстуальному закріпленні в нормативно-правових актах (інших джерелах) [7, с. 108]. Формальна визначеність надає чіткості, однозначності, зрозумілості, стислості та визначе- ності правовим приписам. Завдяки їхній формальній визначеності суб'єкти права знають надані їм права, а також обізнані про обсяг і вид відповідальності за вчинене протиправне діяння [7, с. 109-110].

Диспозиція норми права, що викладена у ст. 485 МК України, сконструйована законодавцем у вигляді «відкритого» (незавершеного) переліку протиправних дій, що спрямовані на ухилення від сплати митних платежів. Вказівка на ознаку протиправності цих «інших» дій та їхню мету не забезпечує чіткості, однозначності, зрозумілості сформульованого законодавчого припису, отже, і його передбачуваності для суб'єктів права. Таке використання засобів законодавчої техніки у визначенні адміністративного правопорушення перетворює диспозицію норми права на «гумову» і загрожує законності правозастосування. Окрім цього, такий законодавчий припис $\epsilon$ корупціогенним чинником, адже відкриває шлях до службових зловживань, довільного, тобто на основі суб'єктивних оцінок, а не формально визначених ознак, тлумачення норми права.

На мою думку, оскільки диспозиція норми права, шо викладена у ст. 485 МК Кодексу, сформульована нечітко та неоднозначно, приписи цієї статті не можна вважати юридично визначеними в аспекті їхньої передбачуваності для суб'єктів правозастосування.

Згідно із ч. 2 ст. 61 Конституції України юридична відповідальність особи має індивідуальний характер. Наведене конституційне положення закріплює принцип індивідуалізації юридичної відповідальності, який має конкретне вираження в галузевому законодавстві.

Відповідно до загальноправового доктринального положення принцип індивідуалізації юридичної відповідальності виражається в диференціації правопорушень і санкцій залежно від суспільної небезпеки правопорушення й особистості правопорушника, встановлення міри й обсягу відповідальності з урахуванням суспільної небезпеки конкретного правопорушення $[8$, c. 248].

Диференціація (від лат. differentia розходження) означає поділ, розчлену- 
вання чого-небудь на окремі різнорідні елементи або цілого на різні частини, форми і ступені [9, с. 301]. Диференціація відповідальності $\epsilon$ правотворчою діяльністю, її підсумком стає створення правових основ індивідуалізації юридичної відповідальності; під час диференціації законодавець окреслює загальний контур, межі караності, зважаючи на ступінь суспільної небезпеки [10, с. 633-634]. Тобто правові можливості диференціації юридичної відповідальності «закладає» законодавець.

В академічній та офіційній конституційній доктрині, а також практиці ЄСПЛ принцип індивідуалізації юридичної відповідальності інтерпретується в тісному зв'язку з іншими її принципами. Найвиразніше цей зв'язок має вияв із принципами справедливості, доцільності, пропорційності.

Індивідуалізація юридичної відповідальності в публічному праві, як зазначає М. Терещук, $€$ своєрідним стержнем, що забезпечує ухвалення справедливого рішення щодо винного. Учений словами професора М.С. Малеїна підкреслює: «якщо відповідальність індивідуалізована, то вона і персоніфікована, і гуманна, і справедлива» [11, с. 95].

Індивідуалізація юридичної відповідальності розглядається також як один з аспектів принципу ії̈ доцільності. У світлі останнього індивідуалізація передбачає можливості пом'якшення відповідальності, її посилення або звільнення від неї, заміну юридичної відповідальності неюридичною, якщо цілі юридичної відповідальності можуть бути досягнені і без неї [12, с. 297].

Це означає обрання такого покарання, яке узгоджується з особистими якостями правопорушника, ступенем суспільної шкоди його вчинку, конкретними обставинами його вчинення, для чого законом передбачено альтернативні та відносно визначені санкцій, які дозволяють ураховувати умови вчинку й індивідуальність винної особи [13, с. 858].

Індивідуальний тягар може бути покладений на особу правовим актом держави тільки тією мірою, яка необхідна для досягнення певної легітимної мети, як зауважує С. Шевчук, що $є$ принципом пропорційності [14, с. 70-71]. Так, ЄСПЛ у рішенні у справі «Мамідакіс проти Греції» визнав, що фінансове зобов'язання, яке виникло внаслідок сплати штрафу, відповідало національному законодавству та задовольняло вимогам суспільного інтересу, проте воно призвело до надмірного навантаження на відповідну особу та суттєво вплинуло на її фінансове становище. За таких обставин, навіть 3 огляду на обґрунтованість застосування відповідного заходу примусу, призначення штрафу завдало такого удару фінансовому становищу заявника, що воно становило непропорційну міру щодо законної мети переслідування, у зв'язку із чим таке стягнення $\epsilon$ несумісним зі ст. 1 Протоколу 1 Конвенції про захист прав і основних свобод людини [15].

Конституційне встановлення принципу індивідуалізації юридичної відповідальності означає його загальноправове значення і реалізацію у будь-якій галузі права (кримінальна, адміністративна, цивільна, трудова тощо).

Зокрема, стосовно реалізації зазначеного принципу у кримінальному праві Суд у рішенні від 2 листопада 2004 р. № 15-рп/2004 зазначив, що окремим виявом справедливості $\epsilon$ питання відповідності покарання вчиненому злочину. Покарання має бути домірним злочину. Справедливе застосування норм права означає недискримінаційний підхід, неупередженість, тобто передбачений законом склад злочину та рамки покарання мають відповідати один одному, а покарання - перебувати у справедливому співвідношенні з тяжкістю й обставинами скоєного й особою винного. Адекватність покарання ступеню тяжкості злочину, як констатував Суд, випливає із принципу правової держави, із суті конституційних прав та свобод людини і громадянина. Тож не маючи можливості призначити більш м'яке покарання, суд не зможе належно індивідуалізувати покарання і забезпечити його справедливість.

Відповідно до позиції Суду конституційний принцип індивідуалізації юридичної відповідальності покладено в основу нормативного встановлення кримінальної відповідальності в законодавстві. Суд уважає, що встановлення законодавцем недиференційованого покарання 
та неможливість його зниження не дозволяють застосовувати покарання до осіб, які вчинили злочини невеликої тяжкості, з урахуванням ступеня тяжкості вчиненого злочину, розміру завданих збитків, форми вини і мотивів злочину, майнового стану підсудного, інших істотних обставин, що $\epsilon$ порушенням принципу справедливості покарання, його індивідуалізації та домірності [16].

Втілюючи засади справедливості, пропорційності і доцільності, як зазначає А. Осауленко, принцип індивідуалізації юридичної відповідальності виступає одним із пріоритетних, адже його вимоги дозволяють на підставі санкції правової норми вибрати найбільш відповідні до тяжкості вчинку й індивідуальних особливостей суб'єкта правопорушення вид і міру юридичної відповідальності [17, с. 16].

Отже, принцип індивідуалізації юридичної відповідальності зобов'язує суб'єкта правозастосування диференційовано підходити до розгляду справи на всіх етапах розвитку правовідносин відповідальності і передбачає необхідність урахування всіх ознак складу правопорушення, його суб'єкта, обставин, які пом'якшують і обтяжують відповідальність, майнового стану особи тощо, а також вибору адекватної міри покарання (стягнення тощо).

Такий підхід реалізував КСУ в рішенні від 21 липня 2021 р. у справі за конституційною скаргою О.А. Одінцової щодо відповідності Конституції України (конституційності) окремих положень абз. 2 ст. 471 Митного кодексу України. КСУ звернув увагу на те, що в разі обмеження права власності в інтересах суспільства необхідними $\epsilon$ не будь-які менш обтяжливі для прав і свобод осіб заходи, а ті з них, які здатні досягти легітимної мети на тому самому якісному рівні. Тобто законодавець зобов'язаний обирати той вид адміністративного стягнення, який менш обтяжливий для прав і свобод особи в конкретному випадку, і насамперед має визначити адекватну міру адміністративної відповідальності для досягнення ії мети, тоді як суди забезпечують індивідуалізацію такої відповідальності залежно від обставин справи в межах законодавчо визначеної санкції (п. 2.4 рішення) [1].
Отже, вибір суб'єктом правозастосування міри юридичної відповідальності може здійснюватися в межах альтернативних та відносно визначених санкцій. Абсолютно визначені (безальтернативні) санкції такого вибору не забезпечують, навіть виключають свободу вибору, оскільки мають імперативний характер і вичерпно визначають вид і кількісну міру державно-правового примусу. Тим самим такі санкції за своїм характером не відповідають принципу індивідуалізації юридичної відповідальності та не сприяють його реалізації на практиці.

Ст. 485 МК України встановлює адміністративну відповідальність за порушення митних правил, що прямо випливає із приписів ч. 5 ст. 2 Кодексу України про адміністративні правопорушення (далі - КУпАП), ст. ст. 458 і 459 МК України, у вигляді штрафу в розмірі $300 \%$ несплаченої суми митних платежів. Така санкція $\epsilon$ абсолютно визначеною, оскільки безальтернативно передбачає тільки один вид адміністративного стягнення за передбачене митне правопорушення - штраф, не встановлює водночас допустимі межі його застосування.

Адміністративній відповідальності властиві всі ознаки і принципи юридичної відповідальності загалом, зокрема й принцип її індивідуалізації. Про справедливість адміністративної відповідальності, як зазначив професор Д. Лук'янець, можна казати тоді, коли правопорушнику відповідно до обставин справи призначається конкретне стягнення на підставі відносно визначеної санкції. Підхід до визначення стягнення повинен бути індивідуальним та враховувати матеріальне становище порушника, його соціальний стан, інші параметри. Це потребує передбачення в законодавстві системи взаємозаміщення адміністративних стягнень, якщо вони не можуть бути виконані за об'єктивними обставинами [18, с. 231-233, 245].

У контексті викладеного варто зауважити, що відповідно до п. 23 розд. 1 Спеціального додатку Н Додатку III до Протоколу про внесення змін до Міжнародної конвенції про спрощення та гармонізацію митних процедур ступінь суворості або обсяг санкцій, застосовуваних 
під час адміністративного врегулювання митного правопорушення, залежить від ступеня серйозності або значущості здійсненого митного правопорушення та від попередньої діяльності відповідної особи, пов'язаної з митною службою.

А згідно з п. 24 розд. 1 Спеціального додатку Н Додатку III до Протоколу про внесення змін до зазначеної Міжнародної конвенції у випадках, коли в декларації на товари зазначені недостовірні дані та декларант може довести, що ним були вжиті всі необхідні заходи для зазначення точної і правильної інформації, митна служба бере цю обставину до уваги під час вирішення питання про застосування санкції [19].

Також відповідно до п. п. 3.2-3.3 ст. 6 розд. I Угоди про спрощення процедур торгівлі кожен член забезпечує, щоб штрафні санкції за порушення митних законів, підзаконних нормативно-правових актів або процедурних вимог застосовувалися лише до особи (осіб), відповідальної (их) за порушення згідно з його законодавством. Застосована штрафна санкція залежить від фактів і обставин справи і повинна відповідати ступеню та тяжкості порушення [20].

КСУ в рішенні від 22 грудня 2010 р. № 23-рп/2010 [21] зазначив, що адміністративна відповідальність та процедура притягнення до неї ґрунтуються на конституційних принципах та правових презумпціях, які зумовлені визнанням і дією принципу верховенства права в Україні. Посилаючись на ст. 33 КУпАП, що закріплює загальні правила накладення адміністративного стягнення за правопорушення, Суд у цьому рішенні підкреслив необхідність індивідуалізації адміністративної відповідальності.

Відповідно до ст. 487 МК України провадження у справах про порушення митних правил здійснюється відповідно до цього Кодексу, а в частині, що не регулюється ним, - відповідно до законодавства України про адміністративні правопорушення. Згідно зі ст. 486 МК України завданнями провадження у справах про порушення митних правил $\epsilon$, зокрема, своєчасне, усебічне, повне й об'єктивне з'ясування обставин кожної справи, вирішення ії з дотриманням вимог закону.
Згідно зі ст. 489 МК України посадова особа під час розгляду справи про порушення митних правил зобов'язана з'ясувати: чи було вчинено адміністративне правопорушення, чи винна дана особа в його вчиненні, чи підлягає вона адміністративній відповідальності, чи $\epsilon$ обставини, що пом'якшують та/або обтяжують відповідальність, чи $\epsilon$ підстави для звільнення особи, що вчинила правопорушення, від адміністративної відповідальності, а також з'ясувати інші обставини, що мають значення для вирішення справи.

Наведені положення міжнародних актів, КУпАП та МК України спрямовані на реалізацію принципу індивідуалізації адміністративної відповідальності, але в умовах абсолютно визначеної санкції ст. 485 МК України практичне застосування цих положень по суті зводиться нанівець. Отже, уважаю, що встановлення в цій статті абсолютно визначеної санкції не сприяє реалізації положень ч. 2 ст. 61 Конституції України і не забезпечує індивідуальний характер юридичної відповідальності особи.

Юридична невизначеність норм права почасти виступає однією із причин суперечливих судових рішень, зумовлює необмеженість суддівського розсуду, що може призвести навіть до суддівського свавілля й ускладнення ефективної реалізації права на судовий захист. Однаковою мірою таке ускладнення може спричинити і неможливість під час судового правозастосування належної індивідуалізації юридичної відповідальності особи. Отже, приписи ст. 485 МК України ускладнюють ефективну реалізацію права на судовий захист і оскарження в суді рішень органів державної влади.

Висновки. Ст. 485 МК України, яка передбачає адміністративну відповідальність у вигляді штрафу у фіксованому розмірі за дії, спрямовані на неправомірне звільнення від сплати митних платежів чи зменшення їхнього розміру, а також інші протиправні дії, спрямовані на ухилення від сплати митних платежів, не забезпечує індивідуальний характер юридичної відповідальності осіб, визнаних винними у правопорушенні, передбаченому цією статтею. Приписи 
цієї статті не можна вважати юридично визначеними в аспекті їхньої передбачуваності для суб'єктів правозастосування, отже, законодавча конструкція цієї статті ускладнює ефективну реалізацію особою права на судовий захист. Зважаючи на це, митне законодавство України має розвиватися шляхом установлення відносно визначених і альтернативних санкцій, що дозволяє індивідуалізувати адміністративну відповідальність за порушення митних правил.

\section{ЛITEРАТУРА:}

1. Рішення Конституційного Суду України (Другий сенат) у справі за конституційною скаргою Одінцової Олени Анатоліївни щодо відповідності Конституції України (конституційності) окремих положень абз. 2 ст. 471 Митного кодексу України від 21 липня 2021 р. № 3-p(II)/2021. URL: https://zakon.rada.gov.ua/laws/card/v003p710-21

2. Резюме конституційної скарги Барсегяна Г.С. (до вх. № 18/7780 від 12 грудня 2019 р.). URL: https://ccu.gov.ua/sites/default/files/18_778019.pdf ; Резюме конституційної скарги Ліненко Н.М. (до вх. № 18/91 від 10 березня 2021 р.). URL: https://ccu.gov. ua/sites/default/files/18_912021.pdf

3. Головатий С. Мірило правовладдя. Коментар. Глосарій. Rule of Law Checklist. Київ : Ваіте, 2017. 163 с.

4. Рішення КСУ від 22 вересня 2005 р. № 5-рп/2005; від 29 червня 2010 р. № 17-рп/2010 ; від 27 лютого 2018 р. № 1-р/2018; від 13 червня 2019 р. № 4-р/2019 ; від 20 червня 2019 р. № 6-p/2019.

5. Конвенція про захист прав людини і основоположних свобод від 4 листопада 1950 р., ратифікована Законом України № 475/97-BP від 17 липня 1997 p. URL: https://zakon.rada.gov.ua/laws/show/995_004\#Text

6. П. п. 52, 64 рішення ЄСПЛ у справі «Вєренцов проти України», 11 квітня 2013 р. URL: https://zakon.rada.gov.ua/laws/show/974_945\#Text

7. Заморська Л. Правова нормативність та її інституціоналізація в Україні : монографія. Одеса : Фенікс, 2013. 304 с.

8. Теорія держави та права : навчальний посібник / Є. Білозьоров та ін. ; за заг. ред. С. Гусарєва, О. Тихомирова. Київ, 2017. 320 с.

9. Великий тлумачний словник сучасної української мови : 250000 слів / уклад. і голов. ред. В. Бусел. Київ ; Ірпінь : ВТФ «Перун», 2005. 1728 с.

10. Хачатуров Р., Липинский Д. Общая теория юридической ответственности : монография. Санкт-Петербург : Юридический центр «Пресс», 2007. 950 с.

11. Терещук М. Юридична відповідальність у публічному праві : дис. ... канд. юрид. наук: 12.00.01. Київ, 2018. 211 с.

12. Общая теория права и государства : учебник / под ред. В. Лазарева. 3-е изд., перераб. и доп. Москва : Юристь, 1999. 520 с.

13. Велика українська юридична енциклопедія : у 20-и т. Харків : Право, 2016. Т. 3 : Загальна теорія права / редкол. : О. Петришин (гол.) та ін. ; Нац. акад. прав. наук України ; Ін-т держави і права імені В.М. Корецького НАН України ; Нац. юрид. ун-т імені Ярослава Мудрого. 2017. 952 с.

14. Шевчук С. Значення загальноправового принципу пропорційності для визначення конституційності законодавчих обмежень щодо реалізації конституційних прав і свобод (зарубіжний досвід). Вісник Академії правових наук України. 2000. № 1. С. 69-76.

15. Рішення ЄСПЛ у справі «Мамідакіс проти Греції» ("MAMIDAKIS c. GRÈCE", заява № 35533/04) від 11 січня 2007 p. URL: https://taxlink.ua/ua/court/sprava-mamidakisproti-grecii

16. Рішення КСУ у справі щодо відповідності Конституції України (конституційності) положень ст.і 69 Кримінального кодексу України (справа про призначення судом більш м'якого покарання). URL: https://zakon.rada.gov.ua/laws/show/v015p710-04\#Text 
17. Осауленко А. Нормативна конструкція ретроспективної юридичної відповідальності в публічному праві сучасної України : автореф. дис. ... канд. юрид. наук., 12.00.01, Київ, 2007. 20 с.

18. Лук'янець Д. Адміністративна відповідальність. Юридична відповідальність: проблеми виключення та звільнення / кол. авт. ; відп. ред. Ю. Баулін. Донецьк : ПП «ВД «Кальмус»», 2013. 424 с.

19. Додаток III до Протоколу про внесення змін до Міжнародної конвенції про спрощення та гармонізацію митних процедур від 26 червня 1999 p. URL: https://zakon.rada. gov.ua/laws/show/976_008\#Text

20. Угода включена як Додаток до Протоколу про внесення змін до Марракеської угоди про заснування Світової організації торгівлі (Протокол ратифіковано Законом України від 4 листопада 2015 р. № 745-VIII). Голос України. 2015. № № 221-222.

21. Рішення КСУ від 22 грудня 2010 р. у справі за конституційним зверненням громадянина Багінського Артема Олександровича щодо офіційного тлумачення положень ч. 1 ст. 14-1 Кодексу України про адміністративні правопорушення (справа про адміністративну відповідальність у сфері забезпечення безпеки дорожнього руху). URL: https://zakon.rada. gov.ua/laws/show/v023p710-10\#Text 